\title{
Challenges to the sub judice rule in South Africa
}

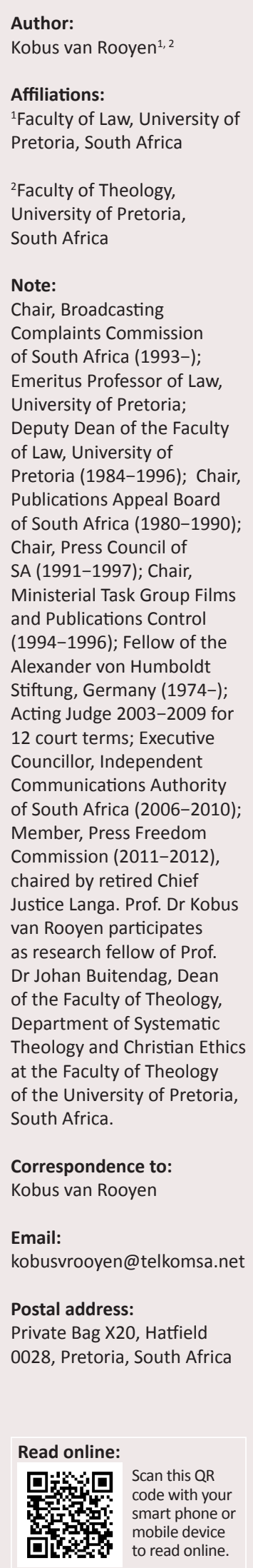

Author:

Affiliations:

${ }^{1}$ Faculty of Law, University of

Pretoria, South Africa

${ }^{2}$ Faculty of Theology,

University of Pretoria,

South Africa

Note:

Complaints Commission

of South Africa (1993-);

meritus Professor of Law,

Deputy Dean of the Faculty

of Law, University of

of South Africa (1980-1990);

Chair, Press Council of

SA (1991-1997); Chair

Ministerial Task Group Films

Alexander von Humboldt

Stiftung, Germany (1974-);

Acting Judge 2003-2009 for

12 court terms; Executive

Councillor, Independent

of South Africa (2006-2010)

Member, Press Freedom

Commission (2011-2012)

van Rooyen participates

as research fellow of Prof

Dr Johan Buitendag, Dean

of the Faculty of Theology,

Department of Systematic

at the Faculty of Theology

of the University of Pretoria,

South Africa.

\section{Correspondence to: \\ Email: \\ kobusvrooyen@telkomsa.net \\ Private Bag X20, Hatfield \\ 0028, Pretoria, South Africa \\ to read online.}

As a lawyer, it is a privilege to contribute to this Festschrift in honour of Professor Doctor Johan Buitendag. His entire career has been a quest for the truth. In the process, he has fearlessly rejected political agendas based on the Bible, and has inspired countless students in their quest to serve God in a practical and humane manner. His published research as well as the output of his doctoral students, both present and past, bear witness to a life dedicated to the search for knowledge in the service of God. He has also assisted substantially in placing South African theological research on the international map. In a sense, this article which deals with the protection of the right to a fair trial of an accused, also acknowledges Johan Buitendag's quest for justice for all South Africans, whatever their creed, gender, race or standing. The subject of my article demonstrates my own quest to promote the constitutional right of an accused to a fair trial, a right that should not be subject to inordinate pressure by the media, and which gives priority to the right of an accused to be presumed innocent: an accused who may frequently suffer loneliness and a sense of rejection. Related to that it is, of course, always important to bear in mind that freedom of expression is at the heart of our democracy. A balance has, accordingly, to be struck between the competing rights.

\section{Introduction}

South African criminal law prohibits the publication of some statements which relate to pending litigation. This is known as the sub judice rule. The rule is in a state of flux as a result of the constitutional guarantee of freedom of expression since 1994. Furthermore, South Africa no longer has a jury system, with the result that the possibility of influencing lay people involved in a court case has fallen away. ${ }^{1}$ Of course, freedom of expression is not an absolute right and is, like all constitutional rights, subject to reasonable limitations. ${ }^{2}$ Anyone following the Oscar Pistorius murder trial in South Africa during 2014 will have experienced substantial discussion in the media on issues (e.g. the weight of evidence) which come close to or possibly squarely fall within what the judge must decide on. The front page heading in the Sunday Times of 13 April 2014, published during cross-examination of Oscar Pistorius ('Oscar is lying') would most probably, in pre-constitutional times, have led to prosecutors seriously considering whether to lay a charge of contempt of court, based on an infringement of the sub judice rule.

As the sub judice rule is still part of South African criminal law, the core question is presently where the limits lie in these post-constitutional times. The constitutional rights which must be weighed against each other are freedom of expression and the right of an accused to a fair trial - which includes the right to be presumed innocent until found guilty by a court. Or, is the constitutional right to a fair trial, as has been argued by eminent Belgian Professor Voorhoof, ${ }^{3}$ only relevant for the process before the court? Of course, the right to freedom of expression is also limited by the right to dignity, which includes reputation and privacy of the accused. The question nevertheless remains: depending on the facts of each case, whether there was indeed an infringement of the said right to dignity and, if so, whether the newspaper or broadcaster was negligent. ${ }^{4}$ But these instances relate to civil liability and do not form part of the sub judice rule. However, it is important to bear in mind that an accused is not without a remedy in civil law.

\footnotetext{
1.Assessors appointed by a judge may be lay people as to the law, but it is suggested that they function so closely with the judge who appoints them, that they would not be influenced by outside pressures.
}

2.See Print Media South Africa and Another v Minister of Home Affairs and Another 2012 (6) SA 443 (CC).

3.Dirk Voorhoof De Media, de verdachte en het vermoeden van onschuld in Auteurs \& Media 2012/1 Vrije Tribune.

4.Mthembi-Mahanyele v Mail \& Guardian Ltd \& Another 2004(6) SA 329(SCA); Le Roux v Dey (Freedom of Expression Institute \& Restorative Justice Centre as Amici Curiae) 2011 (3) SA 274 (CC). Intention is required where the injurious statement is not made in a newspaper.

Dates: Received: 06 May 2014 | Accepted: 01 June 2014 | Published: 20 Nov. 2014

How to cite this article: Van Rooyen, K., 2014, 'Challenges to the sub judice rule in South Africa', HTS Teologiese Studies/Theological Studies 70(1), Art. \#2714, 9 pages. http://dx.doi.org/10.4102/hts.v70i1.2714

Copyright: @ 2014. The Authors. Licensee: AOSIS OpenJournals. This work is licensed under the Creative Commons Attribution License. 
The South African Press and Broadcasting Codes also protect the said dignity rights and when a complaint of infringement is lodged, the said bodies have jurisdiction to find against a newspaper or a broadcaster, after publication. Both codes also require that news must be fair. However, they do not include the sub judice rule as such: contraventions in this respect fall exclusively within the jurisdiction of the criminal courts.

Although justice is a legal concept it, most certainly, also has its roots in religion. One finds, limiting the matter to Christianity for purposes of this article, the requirement of justice in the Old Testament (Pr 1:3; Dt 16:19-21) as well as in Jesus' Beatitudes (Mt 5:6). Of course, the perspective on justice tends to differ from time to time. One only needs to contemplate the burning of Servetus at the stake in the 16th century for his argument against the existence of the Trinity. ${ }^{5}$ Calvin's plea that he 'only' be stabbed to death had no effect on the Protestant churches which demanded that he be burnt at the stake. Of course, add to that the trial and crucifixion of Jesus, which was clearly unlawful ${ }^{6}$ and, bearing in mind the terrible suffering on the cross, undiluted savagery: of course, not only in the case of Jesus, but in all instances, which includes, to my mind, the death sentence by any means.

The apartheid government often stated that its policy was based on Christian principles. It even included Christian principles as a basic norm in the 1974 Publications Act and, policy-wise, spoke of Christian National Education. ${ }^{7}$ It was as if other religions did not exist. ${ }^{8}$ Matters changed, however, when the 1994 Constitution $^{9}$ was passed by parliament. Our Constitutional Court has recognised the important role that religion has played in building South African society, but has also held that religion is not a criterion or source when deciding whether a law is in accordance with the Constitution..$^{10}$ Thus, same sex marriages have been held to be permissible according to the Constitution, in spite of

\section{See Wikipedia under Servetus.}

6.Cf. Bill O'Reilly and Martin Dugard Killing Jesus (2013, Henry Holt and Co., New York, NY).

7.For an overview cf. Van Eeden and Vermeulen 'Christian National Education (CNE) and People's Education (PE): Historical perspectives and some broad common grounds' New Contree no 50 (Nov 2005) - accessible on the internet.

8.Freedom of religion was, however, recognised. 'Christian democracy' is, of course, not unique for South Africa. It finds its roots in the time of Pope Leo XIII in the 19th century and several political parties, add 'Christian' to the names of their parties. Examples of Christian democratic parties include Germany's Christian Democratic Union (CDU), Chile's Christian Democratic Party, Switzerland's Christian Democratic People's Party, the Netherlands' Christian Democratic Appeal (CDA), and Italy's Union of Christian and Centre Democrats (UDC).

9.Now, the Constitution of the Republic of South Africa 1996.

10.Minister of Home Affairs v Fourie (Doctors for Life International and Others, Amici Curiae); Lesbian and Gay Equality Project and Others v Minister of Home Affairs 2006(1) SA 524(CC). 'It is one thing for the Constitutional Court to acknowledge the important role that religion plays in our public life, and quite another for it to use religious doctrine as a source for interpreting the Constitution. It would be out of order to employ the religious sentiments of some as a guide to the constitutional rights of others. Judges would be placed in an intolerable situation if they were called upon to construe religious texts and take sides on issues that have caused deep schisms within religious bodies.' (Paragraph [92] of the judgement). 'The Constitution contains a number of provisions that underline the constitutional value of acknowledging diversity and pluralism in our society, and give a particular value of acknowledging diversity and pluralism in our society, and give a particular texture to the broadly phrased right to freedom of association contained in s 18 . Taken together, they affirm the right of people to self-expression without being forced to subordinate themselves to the cultural and religious norms of others, and highlight the importance of individuals and communities being able to enjoy what members of communities to depart from a majoritarian norm.' (Paragraph [61]) [Quotes from the head note of the judgement]. arguments from a religious perspective before the court which condemned such unions. The same argument applies to abortion on request, which is also permitted by law within certain limits. ${ }^{11}$ A new Films and Publications Act was also passed by parliament in 1996 and all religions were granted equal protection by way of a hate speech clause in the act. $^{12}$ It is well known that the death sentence was declared unconstitutional by the Constitutional Court of South Africa in $1994 .^{13}$

\section{The Midi case}

Getting back to the sub judice rule: the basic rule was that anyone who published a statement which had the tendency of influencing the merits of a pending court matter, was guilty of the offence of contempt of court. The South African Supreme Court of Appeal has, however, in 2007 espoused a much more lenient approach to the rule in Midi Television (Pty) Ltd t/a E-TV v Director of Public Prosecutions. ${ }^{14}$ Its approach was based on the fundamental right of freedom of expression which, as from 1994, provides substantially more freedom than in the apartheid years. In pre-constitutional times, an act of parliament could not be declared invalid on grounds that it was in conflict with basic human rights, parliament having been the supreme legislative body. Under the 1994 and 1996 Constitution, parliament is no longer sovereign. The Constitution, as applied by the Constitutional Court, is the highest source of rights and duties.

In the Midi matter the Cape Director of Public Prosecutions demanded that Midi Television provide it with film footage relating to a murder, which Midi had in its possession. Midi was not willing to do so and the Cape High Court ordered it to hand the footage to the director. Midi appealed to the Supreme Court of Appeal arguing that it was under no legal obligation to hand the footage to the prosecution. The Supreme Court of Appeal upheld the appeal and stated that there was no law which compelled the broadcaster to hand the footage to the prosecution.

In its judgement the Supreme Court of Appeal, ${ }^{15}$ however, also expressed a view on the influence of the constitutional right to freedom of expression, introduced in 1994, on the sub judice rule. There are also other forms of contempt of court, ${ }^{16}$ but I will limit this article to the sub judice rule.

Judge of Appeal Nugent stated the following in regard to the scope of the sub judice rule in post-constitutional times:

11.Christian Lawyers Assoc of SA v Minister of Health 1998 (4) SA 1113 (T).

12.As to the continued existence in South African law of blasphemy, a Judaeo Christian concept, see my article: 'Does the offence of blasphemy have a future under the South African Constitution?', 1995 Hervormde Teologiese Studies 1127.

13.S v Makwanyane 1995 (3) SA 391 (CC)

14.Midi Television (Pty) Ltd t/a E-TV v Director of Public Prosecutions (WC) 2007 (5) SA 540 (SCA).

15.This is the highest appeal court in the country in ordinary matters. However, in constitutional matters an appeal is possible to the Constitutional Court.

16.Scandalising the court (where a judge is dealt with in a seriously demeaning manner, for example in a newspaper), contempt of court, for example, reading a newspaper or smoking or shouting in court and contempt of court where an order newspaper or smoking or shouting in court and contempt of court where an order
of court is not abided by intentionally. Cf. Milton South African Criminal Law and of court is not abided by intention
Procedure (vol. 2, 1996) 163 et seq. 
[12] It is an established rule of the common law that the proper administration of justice may not be prejudiced or interfered with and that to do so constitutes the offence of contempt of court. That is now reinforced by the constitutional right of every person to have disputes resolved by a court in a fair hearing and by the constitutional protection that is afforded to a fair criminal trial. It is not contentious in all open and democratic societies - and it was not contentious before us - that the purpose that is served by those principles of law provides a proper basis for limiting the protection of press freedom, and the reason for that is self-evident. The integrity of the judicial process is an essential component of the rule of law. If the rule of law is itself eroded through compromising the integrity of the judicial process then all constitutional rights and freedoms -including the freedom of the press - are also compromised.

[13] The exercise of press freedom has the potential to cause prejudice to the administration of justice in various ways - it is prejudicial to prejudge issues that are under judicial consideration, it is prejudicial if trials are conducted through the media, it is prejudicial to bring improper pressure to bear on witnesses or judicial officers - and it is not possible to describe exhaustively how prejudice might occur. What is more relevant in all cases where there is the potential for prejudice is to determine when the risk of prejudice will be sufficient to constitute an interference with the administration of justice that justifies a corresponding limitation being placed on press freedom. For the administration of justice does not take place in private, completely shielded from public scrutiny and comment, and there is always the potential for some element of prejudice when the media report or comment on judicial proceedings. What must be guarded against, as pointed out by Justice McLachlin in a concurring opinion in Dagenais $v$ Canadian Broadcasting Corporation $^{17}$ is the 'facile assumption that if there is any risk of prejudice to a fair trial, however speculative, [a ban on publication] should be ordered'. (Emphasis added)

The Supreme Court of Appeal went so far as to reject two of its judgments from pre-constitutional times where a wide limitation was applied to what could be published in relation to pending court cases. One judgement had to do with a case where a newspaper editor published notes, wrongly believing the notes to have been written by a judge and read into the record, ${ }^{18}$ the other judgement related to an academic who, during a pending trial, in a public lecture exhorted judges to ignore any evidence by persons who had been in detention without trial. At the time persons could be detained without trial for up to 180 days. It should be mentioned that detention without trial for longer than 48 hours is presently not in accord with the Constitution of the Republic of South Africa. In a state of emergency it is permissible for 10 days under stringent conditions. ${ }^{19}$

\section{7.[1994] 25 CRR (2d) ([1994] 3 SCR 835).}

18.A similar approach in S v Harber 1988 (3) SA 396 (A) was also disapproved of. Judge of Appeal Nugent (in Midi) states as follows: 'In my view nothing less is required in this country and to the extent that the pre-constitutional decisions of this court in Van Niekerk and Harber might suggest otherwise I do not think they are consistent with what is to be expected in contemporary democracies. But merely to ask whether there is indeed a risk of prejudice that meets those criteria does not end the enquiry. For as I indicated earlier, the limitation must not only be directed towards a permitted end, but must also be no more than is necessary to achieve its permitted purpose.'

19.See section 37(6) of the Constitution of the Republic of South Africa 1996. The general rule is that a maximum detention without trial must not be longer than
ten days unless a court orders otherwise as a result of the necessity for restoring ten days unless a
As mentioned, the pre-constitutional test was whether the published material had the tendency to influence the outcome of a court case. As appears from the above, the accent is now on a real risk of prejudice. Nevertheless, as pointed out by the Supreme Court of Appeal, it is prejudicial to prejudge issues that are under judicial consideration, if trials are conducted through the media, to bring improper pressure to bear on witnesses or judicial officers: and that it is not possible to describe exhaustively how prejudice might occur. However, as pointed out by the court, the true question to answer is at what stage the limits are overstepped. The only guidance provided by the court is the following: '[W]hat must be guarded against', as pointed out by Justice Beverley McLachlin in a concurring opinion in Dagenais $v$ Canadian Broadcasting Corporation ${ }^{20}$ is the 'facile assumption that if there is any risk of prejudice to a fair trial, however speculative, [a ban on publication] should be ordered.' Justice McLachlin, ultimately, stated that the court must require a rational connection of the publication with the court case and minimal impairment of freedom of expression. The mere tendency will no longer suffice. Justice McLachlin, however, clearly indicated that the right of an accused to a fair trial may never be compromised.

\section{Canada, New Zealand, Australia, England, India, Germany and the United States of America}

Dagenais $v$ Canadian Broadcasting Corporation, ${ }^{21}$ referred to by Judge of Appeal Nugent in Midi, provides a good example of material which was found not to have prejudiced the administration of justice: the respondents, members of a Catholic religious order, were charged with physical and sexual abuse of young boys in their care at training schools in Ontario. They applied to a superior court judge for an injunction restraining the $\mathrm{CBC}$ from broadcasting the miniseries The Boys of St Vincent, a fictional account of sexual and physical abuse of children in a Catholic institution in Newfoundland, and from publishing in any media any information whatsoever relating to the proposed broadcast of the programme. At the time of the hearing, the trials of the four respondents were in the process of being heard or were scheduled to be heard in the Ontario Court of Justice before a judge and jury. The trial of one of the respondents, LD, was in its final stage, and a trial judge had been appointed for the case of another respondent, LM. The Supreme Court set aside the injunction of the lower courts. The rule laid down by Chief Justice Lamer and three other justices (the majority) is quoted with approval by Judge of Appeal Nugent in the passages quoted from Midi above.

The core of the thinking of the Supreme Court of Canada is stated by the then Chief Justice Lamer:

[T] he common law must be adapted so as to require a consideration of both the objectives of the publication ban, and

20.[1994] 25 CRR (2d) ([1994] 3 SCR 835).

21.[1994] 25 CRR (2d) ([1994] 3 SCR 835). 
the proportionality of the ban to its effect on protected Charter rights. The modified rule may be stated as follows: A publication ban should only be ordered when:

(a) Such ban is necessary in order to prevent a real and substantial risk to the fairness of the trial, because reasonably available alternative measures will not prevent the risk; and (b) The salutary effects of the publication ban outweigh the deleterious effects to freedom of expression of those affected by the ban.

In a concurring judgement Justice Beverley McLachlin (presently the Chief Justice of Canada) reasoned as follows as to the applicable test:

Under the proportionality branch of the Oakes ${ }^{22}$ test, a publication ban may be justified where there are special circumstances [where circumstances] which indicate a serious risk to the fairness of the trial, and provided that the ban goes no further than required to avoid the risk. ... It is not a question of deciding where the balance should be struck between a fair trial and freedom of expression. The right to a fair trial is fundamental and cannot be sacrificed. In general, the clash model is also largely inappropriate. The common law test governing the issuance of publication bans, properly applied, meets the requirements of justification of an infringing measure in Section 1.

What is required is that the risk of an unfair trial be evaluated after taking full account of the general importance of the free dissemination of ideas and after considering measures which might offset or avoid the feared prejudice. Here, the judge ordering the ban failed to direct herself to the considerations which go to establishing rational connection and minimal impairment. It follows that the ban cannot be supported and must be set aside. (Emphasis added)

The approach in Dagenais was, however, rejected by the New Zealand Court of Appeal in Gisborne Herald Co. Ltd. $v$ Solicitor General. ${ }^{23}$ Judge Richardson stated:

$[T]$ he complex process of balancing the values underlying free expression may vary from country to country, even though there is a common and genuine commitment to international human rights norms. The balancing will be influenced by the culture and values of the particular community... The result of the balancing process will necessarily reflect the Court's assessment of society's values. ${ }^{24}$

The New Zealand test, based on the tendency to interrupt, thus remains the same as the pre-constitutional test applied by South African courts.

In Australia the tendency test has also been applied, but with an addition: ' $[A] \mathrm{s}$ a matter of practical reality, a tendency to

22.For ease of reference the test laid down in Oakes is quoted: 'The party seeking to justify the limitation of a right (in the case of a publication ban, the party seeking to limit freedom of expression) bears the burden of justifying the limitation. The to limit freedom of expression) bears the burden of justifying the limitation. The party claiming under the common law rule that a publication ban is necessary
to avoid a real and serious risk to the fairness of the trial is seeking to use the to avoid a real and serious risk to the fairness of the trial is seeking to use the
power of the State to achieve this objective. A party who uses the power of the
State against others must bear the burden of proving that the use of State power State against others must bear the burden of proving that the use of State power
is justified in a free and democratic society. Therefore, the party seeking the ban bears the burden of proving that the proposed ban is necessary, in that it relate to an important objective that cannot be achieved by a reasonably available and effective alternative measure, that the proposed ban is as limited (in scope, time, content, etc) as possible, and there is a proportionality between the salutary and deleterious effects of the ban. At the same time, the fact that the party seeking the ban may be attempting to safeguard a constitutional right must be borne in mind when determining whether the proportionality test has been satisfied.'

23.[1995] 3 NZLR 563. See Background Paper on 'Freedom of Expression and Contempt of Court for the International Seminar on Promoting Freedom of Expression', Hilton Hotel London, United Kingdom 29-30 November 2000 (author not stated).

24.At page 575 interfere with the due course of justice in a particular case ${ }^{25}$. This test has been applied in numerous Western Australian cases. In New South Wales a refinement of the test is to be found in $R v$ Pearce $^{26}$ where the following was stated:

If the publication is of a character which might have an effect on the proceedings, it will have the necessary tendency, unless the possibility of interference is so remote or theoretical that the de minimis principle should be applied.

The Law Reform Commission of Western Australia proposed the following approach to be followed in legislation:

A publication should constitute contempt if it creates a substantial risk, according to the circumstances at the time of publication, that:

(a) a witness or witnesses, or potential witness or witnesses, in legal proceedings could:

(i) encounter the publication; and

(ii) recall the contents of the publication at the material time; and

(b) by virtue of those facts, the fairness of the proceedings would be prejudiced.

It was also recommended that the legislation should include a requisite state of mind (in other words negligence or intention). ${ }^{27}$

In India the Criminal Contempt of Courts Act 1971 inter alia defines criminal contempt of court as:

[T] he publication (whether by words, spoken or written, or by signs, or by visible representation, or otherwise) of any matter or the doing of any other act whatsoever which prejudices, or interferes or tends to interfere with the due course of any judicial proceeding.

The 'tends' corresponds to the earlier South African test.

In England the test is set out in judgments of the courts and is partly specified in the Contempt of Court Act 1981. In so far as the sub judice rule is concerned, it is impermissible to publish anything which creates a real risk that the course of justice in ongoing proceedings may be seriously impaired. This test accords with the Canadian and present South African approaches to the sub judice rule.

In the United States of America the leading case is the 1931 Near $v$ Minnesota. ${ }^{28}$ Near published a scandal sheet in Minneapolis, in which he accused local officials for being implicated with gangsters. Minnesota officials obtained an injunction to prevent Near from publishing his newspaper under Minnesota legislation that permitted pre-censorship of periodicals. The law provided that any person 'engaged in the business' of regularly publishing or circulating an 'obscene, lewd, and lascivious' or a 'malicious, scandalous

\section{John Fairfax \& Sons Pty v McRae (1954) 93 CLR 351.}

26.Attorney General (NSW) v John Fairfax \& Sons Ltd (1980) 1 NSWLR 362, 368 Compare The Report on Review of the Law of Contempt (June 2003 - Law Reform Commission of Western Australia - accessible on the internet).

27.I have left out the reference to juries, since that is not relevant for South Africa. 28.283 US 697(1931). 
and defamatory' newspaper or periodical was guilty of a nuisance, and could be interdicted from further committing or maintaining the nuisance. ${ }^{29}$

The Supreme Court of the United States had to decide whether the law violated the free press provision of the First Amendment. Five justices out of nine held in Near's favour, holding that the law authorising the ban was unconstitutional. The court justified its decision with reference to the fact that the protection against prior restraint lay at the heart of the First Amendment, which guarantees freedom of expression. The court held that the statute constituted a prior restraint and was, accordingly, invalid under the First Amendment. Hereby a constitutional principle was established that, with some narrow exceptions, the government could not censor or otherwise prohibit a publication in advance, even though the communication might be punishable after publication in a criminal or other proceeding. This principle also applies to a court, which is not permitted to prohibit the publication of ongoing proceedings, because that would amount to censorship. In other words, only in very special cases would a court be permitted to order such a restraint, for example in time of war, where the information is likely to prejudice the war effort.

In Germany the constitutional guarantee of freedom of the press has also granted more freedom for the press to comment on pending court cases. The only remedy for an accused would be to claim damages based on defamation or impairment of dignity. ${ }^{30}$

\section{The European Court of Human Rights}

The European Court of Human Rights in Strasbourg has also dealt with limitations of member states on media coverage of trials within the guarantee of freedom of expression in article 10 of the Convention for the Protection of Human Rights and Fundamental Freedoms. In Worm $v$ Austria, ${ }^{31}$ a journalist had published an article which strongly suggested that a government minister, who was on trial for tax evasion, was guilty. The Strasbourg Court held that there was no violation of the right to freedom of expression when the journalist was found guilty of a contravention of section 23 of the Austrian Media Act, which prohibited the publication of matters considered capable of influencing the outcome of criminal proceedings. However, in its Sunday Times judgement, ${ }^{32}$ the court held that publications dealing with thalidomide damage to unborn babies did not justify an injunction against their publication in spite of pending litigation on the matter. The Strasbourg Court stated the following:

If the issues arising in litigation are ventilated in such a way to lead the public to form its own conclusion thereon in advance,

29.Sourced from Wikipedia.

30.Information provided by Professor Dr Joachim Hermann, University of Augsburg; also see Axel Springer AG v Germany ECHR Case No 39954/08 (07 Feb 2012).

31.29 August 1997, Application 22714/93, 25 EHRR 454.

32.The Sunday Times v. United Kingdom, 26 April 1979, Series A No. 30, 14 EHRR 229. it may lose its respect for and confidence in the courts. Again, it cannot be excluded that the public's becoming accustomed to the regular spectacle of pseudo-trials in the news media might in the long run have nefarious consequences for the acceptance of the courts as the proper forum for the settlement of legal disputes. (Emphasis added)

More recent judgements of the Strasbourg Court also demonstrate an accent on freedom of expression. It for example set aside an award of damages against an Austrian newspaper publisher for having disclosed the name of a bank manager whose name was mentioned as a suspect in a fraud investigation. The reasoning of the Austrian court was that the bank manager was not a 'public official' and that there had been no reason to identify him. The Strasbourg Court, however, found that although the manager was not a public official, there had been sufficient reason to mention persons involved, including persons in the financial and political fields. It would have been difficult, according to the court, not to have mentioned his name. ${ }^{33}$

Axel Springer AG v Germany ${ }^{34}$ related to the coverage by the newspaper Bild of the arrest and conviction of a famous TV-actor found in possession of drugs. The actor had acted the part of a police superintendent as the hero of a popular television series on German TV, with a viewership of between three and five million. The actor successfully applied for an injunction against the further publication of two articles: one on his arrest for possession of cocaine and the other for the publication of his conviction. The Strasbourg Court, however, set aside these injunctions on the basis that it was in the public interest and that the injunctions were not necessary in a democratic society. The public interest increased as a result of his involvement as a (fictional) law enforcement officer in the series on television. Furthermore, he had been arrested in a public place (a beer hall) and all the facts published were correct.

Recently the German Bundesgerichtshof ${ }^{35}$ held that the media was entitled to publish intimate details of the life of a weather anchor on television. The facts, according to the court, became public when revealed during the arrest hearing of the anchor. The fact that he was exonerated on the charge of rape, did not assist. The decision of the Oberlandesgericht in his favour was set aside.

In Finland the editor and the producer of a programme, Ristamäki and Korvola, working at the news service of the National Finland broadcaster, were found guilty of an offence in that they had broadcast a programme concerning a well-known businessman who, at the time, was standing trial for economic offences. They were convicted of having intentionally made false insinuations about the businessman,

33.Standard Verlags v Austria (ECHR 10 January 2012).

34.ECHR Case No 39954/08 (07 Feb 2012).

35.Aktenzeichen: VIth Zivilrechtssenat, case no. 93 of 2012. Except for the Constitutional Court, the Bundesgerichtshof is the highest court in Germany. My
Concer gratitude is expressed to Professor Dr Joachim Herrmann from Augsburg, who gratitude is expressed to Professor Dr Joachim Herrmann from Augsburg, who
provided the facts to me per email. The case is also accessible on the internet under Kachelman. 
because their conduct had been conducive to causing suffering to him and subjecting him to contempt and causing him damage. The Helsinki District Court convicted them of defamation in terms of the Finland Criminal Code. They were sentenced to fines amounting to approximately EUR2000.00 each and ordered to pay the complainant EUR1800.00 for suffering and EUR1500.00 for costs. ${ }^{36}$

The Strasbourg Court referred to its judgement in the Axel Springer matter and the importance of reporting on the malfunctioning of the administration in two specific cases that both involved influential persons. The persons were mentioned in the programmes as examples, whilst the rest of the programme focused on the tax authorities. The matter was, indeed, in the public interest. The facts broadcast were not in dispute and they were dealt with in an objective manner. There was also no evidence of bad faith. The court found that there had been a violation of article 10 of the convention, which guarantees freedom of expression. This meant that the convictions were not justified.

Similarly the Strasbourg Court held that the conviction for defamation of an Italian editor, reporting on matters concerning the 'war' between judges, prosecutors and the police in the context of combating the Mafia, was in conflict with the guarantee of freedom expression in article $10 .^{37}$

\section{Broadcasting Complaints Commission of South Africa and the Press Ombudsman}

Before I finally attempt to reach a conclusion, it is necessary also to bear in mind that alternative remedies are to be found in the codes of the Broadcasting Complaints Commission of South Africa (BCCSA) and the Press Council. Both these bodies have been set up by the relevant media, and membership is voluntary. Only a few minor media outlets are not members. The Press Council has been active since 1962 and the BCCSA since 1993. Both bodies only act upon a complaint and only after a broadcast or a publication in a newspaper or magazine. They can order corrections as well as a right to reply. The codes of these bodies require that news must be fair and that comment on matters of public importance must be balanced and based on the truth or what is reasonably perceived to be the truth. Rights of dignity and privacy are protected and a right of reply is granted in matters of public importance.

In so far as court reporting is concerned, the BCCSA dealt during 2013 with a complaint from a member of the public, who argued that a radio station had breached the Broadcasting Code by broadcasting, as part of one of its news bulletins, a comment from the mother of one of the girls

36.ECHR Case 66456/09. Recognition is given to Professor Dirk Voorhoof's summaries of the latest judgments in IRTS - Legal Observations of the European Audiovisual Observatory.

37.Belpietro v Italy ECHR Case no 43612/10 (24 September 2013). who had allegedly been raped by a man, called the 'Sunday rapist'. The accused had given evidence the previous day and denied having known or raped the young ladies whom he had allegedly raped and murdered. The mother of one of the girls, thereupon, from the public gallery called out that he was lying, or words to that effect. The judge admonished her. After the proceedings that day a reporter from the radio station had an interview with her, which was broadcast as part of a news bulletin:

News Presenter: 'Staying with the courts, the mother of one of the Sunday rapist's alleged murder victims Louise De Waal says she was shocked to hear him say he never met her daughter. Johannes Steyn today took the stand in the Palm Ridge Magistrates Court to testify in his own defense. He faces 37 charges including two of murder and 11 of rape. Andrea van Wyk reports from Palm Ridge.'

Reporter Andrea van Wyk: 'Louise de Waal's mother Shereen says hearing Steyn's testimony has been difficult for her.'

Shereen: 'Maybe at the time obviously when he took her he didn't know her but he knows her now, he knows himself that he took her and who she is and exactly the person she was. So I don't see how he can even deny that.'

Andrea van Wyk: 'Shereen gasped when Steyn told the court this and said she didn't believe him. Steyn has been testifying as to what he did on the day of Louise's murder. Andrea van Wyk eye witness news, Palm Ridge.'

The BCCSA tribunal ${ }^{38}$ held that as news had to be fair, the item gave an unfair rendition of the court proceedings. The comment of the mother amounted to extraneous evidence which was not before the court. Had she been a witness in the trial, she would have been subjected to cross-examination and the result of such cross-examination could then have been broadcast. The tribunal considered the Midi judgement, but came to the conclusion that the tribunal's finding on fairness was not related to the sub judice rule, but only concerned the question whether a fair rendition had been given of the trial. On appeal against the finding, the appeal tribunal confirmed the decision of the tribunal. However, the appeal judgement also included references relating to the protection of the administration of justice. ${ }^{39}$

The press ombudsman required a Sunday newspaper to apologise to paralympian star Oscar Pistorius, who was then awaiting trial, for implying that he had a new girlfriend and was once again living the life of a celebrity after buying an Audi R8 sports car. The truth was that the female was his cousin and that he was merely assisting in the paperwork for the purchase of the car by his uncle, the father of his cousin.

\section{A moral dimension}

A few years ago, when the then leader of the African National Congress (ANC) Youth League, Julius Malema, was

38.Judgments Online [2013] 30248(BCCSA).

39.Judgments Online [2013] 30239(BCCSA). 
brought before the South African Equity Court for singing the liberation struggle song, 'Kill the Boer - Kill the farmer', some supporters were chanting these very words outside the court. The voice of the supporters, if broadcast, could have implied, either directly or indirectly, that the respondent was innocent of any contravention of the law: the argument being that the chanters should be free to chant the song because it had its origins in oppressive apartheid times. Malema was found to have been in contravention of the Equality Act. He appealed, but the matter was settled amicably between the complainant and the ANC. High-profile cases are generally in the public interest, and people have a right to take part in the debate, supporters of freedom of expression would argue. That would be morally and politically necessary within a nation, the majority of which had suffered under apartheid.

Modimolle, which means 'God has eaten', is a small town in the northern part of South Africa, established in the 19th century by a group of Christians who believed that they had found the Nile and then called it Nilestream. ${ }^{40}$ Of course, in reality the Nile finds its source thousands of miles to the north-east. Their suspicion was confirmed by what appeared to be a pyramid, which is, however, merely an outcrop in a mountain range. The name of the town was changed by the town council to Modimolle a few years ago. Given the history of the town's founding, this is an unlikely place in which to find a man who had been found guilty of murder and rape of his wife by men whom he had commanded for the task. During his trial he was dubbed the 'Modimolle monster'. A new dimension was added to the media scene when Nobel Peace Prize laureate Archbishop Emeritus Desmond Tutu accused the media of demeaning behaviour in calling the alleged murderer and rapist a monster. $\mathrm{He}$ argued that no human being, created by God, may be called a 'monster' as redemption was always possible. ${ }^{41}$ This view was attacked vehemently in an article by a South African commentator, Masango, who argued that nothing could ever redeem the pre-1994 apartheid government's cruelty to blacks. ${ }^{42}$ Therefore, the archbishop, according to Masango, was wrong. I am inclined to agree with the Nobel laureate: no person who stands trial should be prejudged to be a monster. I must also agree with the point of view of Masango: the apartheid policy, generally led to monstrous deeds against the disenfranchised. In fact, this was conceded by the archbishop, whose point of view was directed at protecting an individual as a creature of God.

40.The famous poet and author Eugene Marais, as well as the sixth prime ministe of South Africa, JC Strijdom, were inhabitants in the first half of the 20th century.

41. He said the following in The Star newspaper (18 January 2012): 'He may indeed be guilty of inhuman, ghastly and monstrous deeds, but he is not a monster. We are actually letting him off lightly by calling him a monster because monsters have no moral sense of right and wrong - and therefore cannot be held morally culpable, cannot be regarded as morally blameworthy, ... (Kotze) remains a child of God with the capacity to become a saint. This may shock some of us We should condemn ghastly acts of awful cruelty but we must, as they say, hate the should condemn ghastly acts of awful cruelty but we must, as they say, hate the sin and love the sinner, or hope that he may change for the better.' The Archbishop emeritus referred to his experience at the South African Truth and Reconciliation been murdered brutally and yet we saw some extraordinary scenes of magnanimity when perpetrator and victim or relative of victim embraced publicly.'

42.Aubrey Masango in the The Daily Maverick online newspaper (08 October 2013).

\section{Conclusion}

Freedom of expression lies at the heart of the South African democracy. ${ }^{43}$ It is, however, necessary to bear in mind that an accused has a constitutional right to a fair trial and that his or her reasonable perception in this regard, it is submitted, is crucial. I also agree with the present Chief Justice of Canada that this right may never be compromised. On the other hand, the value of freedom of expression as a fundamental right has overwhelmed countries where democratic values are held dear: especially where they have suffered under totalitarian regimes. Furthermore, judges, as a result of their experience and expertise, ignore what the press and broadcasters say. They only consider the facts before them. There is also a tendency, within some democracies, to soften the effect of the sub judice rule. One experiences that from the Canadian judgement in Dagenais, the South African judgement in Midi and the approach of the European Court of Human Rights, as discussed above: and also, of course, from the approach of the United States courts. Proposals in Australia also tend towards more freedom and England has also adopted a reality test.

From a legal point of view my conclusion on the sub judice rule is that it should constantly, in reporting on a pending trial, be borne in mind that it is the judge who must ultimately decide on the weight of the evidence and the guilt of the accused. However, it is also well known that judges, who are bound by their oath, only decide matters on the facts as placed before them in the matter at hand. They would ignore any opinions expressed in the media. ${ }^{44}$

In the South African Midi and the Canadian Dagenais judgements as well as the English Contempt of Court Act 1981, there is a clear swing towards a real application of the sub judice rule in contrast to an ideological one. No closer guidance is given by the judgments or the English act. What is 'real' will have to be decided by the courts from case to case. Philosophically this approach also underlies the thinking, which I support, that criminal law should only intervene as a last resort within the sphere of freedom of expression. It is, in fact, interesting to note that hate speech has not, in South Africa, been regarded by parliament as a criminal act. An interdict, ${ }^{45}$ a finding in terms of the Equality Act, ${ }^{46}$ a prohibition of the distribution of a film or publication

43.See Print Media South Africa and Another v Minister of Home Affairs and Another 2012 (6) SA 443 (CC).

44.Cf. Irish Judge O' Hanlon in Desmond v. Glackin (No1) [1992] I.L.R.M. 490 at 505 (HC). Desmond v. Glackin (No. 1) 12 the public comments on radio of the Minister for Industry and Commerce concerning a matter of public controversy were said to have prejudiced judicial review proceedings which were them pending. O'Hanlon stated '... it is generally considered improper and unlawful to publish material which prejudges issues for determination by the court in pending proceedings ...' O'Hanlon was unimpressed with the claim of contempt and stated that he did not consider that the interview made 'it difficult for a judge of the High Court ... to decide in an objective and unbiased manner the legal issues which arise for consideration in these proceedings" Cf Paul Anthony McDermott "Contempt of Court and the need for legislation' writing from an Irish perspective in 2004 Judicial Studies Institute Journal 185 (accessible on the internet).

45.Compare Jamiat-UI-Ulama of Transvaal v Johncom, Media Investment and Others WLD case $1127 / 2006$, where the Danish newspaper cartoons of the Prophet Mohamed were interdicted from publication in all media in South Africa. 
without any merit ${ }^{47}$ and a post publication finding against a newspaper or broadcaster may be made by the press ombudsman or the BCCSA ${ }^{48}$ : but that is as far as it goes.

The 'free marketplace of ideas' probably lies at the heart of a more moderate approach. The concept was first put forward by John Stuart Mill in his book, On Liberty, in 1859. Later on it was used in opinions of the Supreme Court of the United States. The first reference to the 'free trade in ideas' within 'the competition of the market' was in Justice Oliver Wendell Holmes' dissent in Abrams v. United States. ${ }^{49}$ The general idea that free speech should be tolerated because it will lead towards the truth has a long history. The English poet John Milton suggested that restricting speech was not necessary because 'in a free and open encounter,' truth would prevail. US President Thomas Jefferson argued that it is safe to tolerate 'error of opinion ... where reason is left free to combat it. ${ }^{50}$

The primary duty to uphold the constitutional rights of an accused lies with the courts. Where there is a real threat to that right in a publication or broadcast, as defined in Midi, ${ }^{51}$ a prosecution for contempt of court should follow if intention is also proved. I suggest that the test for a 'real' threat is not readily attainable: the circumstances would have to be extraordinary.

I must, however, add the following cautionary note as to the sub judice rule. The Midi judgement has stated what the requirements are in what one may, with respect, call vague terms. However, because it has not itself applied the sub judice rule in the case before it, there is no factual position which guides one for the future, except that it would not have found a breach in cases similar to Van Niekerk and Harber, which it rejected as applicable within our present democracy. ${ }^{52}$ Yet, Midi has kept three categories intact:

$[I] \mathrm{t}$ is prejudicial to prejudge issues that are under judicial consideration, it is prejudicial if trials are conducted through the media, it is prejudicial to bring improper pressure to bear on witnesses or judicial officers - and it is not possible to describe exhaustively how prejudice might occur.

The court does, however, caution that what must be guarded against is the facile assumption that if there is any risk of prejudice to a fair trial, however speculative, a finding of breach of the sub judice rule must follow: and thus incorporates Canadian Justice McLachlin's cautionary rule. Furthermore, the following guidance is provided by the Midi judgement:

[19] In summary, a publication will be unlawful, and thus susceptible to being prohibited, only if the prejudice that

47.Compare sections 16 and 18 of the Films and Publications Act 65 of 1996.

48.Clause 4 of the Broadcasting Code and clause 5 of the Press Code.

49.250 U.S. 616,630 (1919).

50.Source: Wikipedia.

51.See note 18 .

52.See note 22 the publication might cause to the administration of justice is demonstrable and substantial and there is a real risk that prejudice will occur if publication takes place. Mere conjecture or speculation that prejudice might occur will not be enough. Even then publication will not be unlawful unless a court is satisfied that the disadvantage of curtailing the free flow of information outweighs its advantage. In making that evaluation it is not only the interest of those who are associated with the publication that need to be brought to account but, more important, the interest of every person in having access to information. Applying the ordinary principles that come into play when a final interdict is sought, if a risk of that kind is clearly established, and it cannot be prevented from occurring by other means, a ban on publication that is confined in scope and in content and in duration to what is necessary to avoid the risk might be considered. (Emphasis added)

Every case will, accordingly, depend on its own facts. It is a question whether, with respect, the Midi criteria are not so vague that they constitute a constitutional nullity. ${ }^{53}$ How could a court apply such a vague definition and, possibly, even have the accused incarcerated ${ }^{54}$ Alternatively, the Constitutional Court will have to provide a workable definition, as it has, for example, done with the vague definition of child pornography in De Reuck $v$ Director of Public Prosecutions and Others. ${ }^{55}$

Where a case can be made out for defamation, invasion of privacy or an impairment of dignity, the necessary steps may be taken by way of an interdict or an action for damages: bearing in mind that an interdict which applies for non-publication in future, is not readily granted by our courts. ${ }^{56}$ In these cases the public interest defence would be applicable. Of course, 'public interest' is not that which is interesting to the public, but a matter which serves a higher societal interest. ${ }^{57}$

This article illustrates how the Constitution of the Republic has also adapted the common law. In fact, there is a constitutional duty on courts and other forums to adapt the common law in accordance with the Bill of Rights. ${ }^{58}$ 53.Compare Islamic Unity Convention v IBA 2002 (4) SA 294 (CC).

54.See Paul Anthony McDermott 'Contempt of Court and the need for legislation' writing from an Ireland perspective in 2004, Judicial Studies Institute Journal 185 (accessible on the internet).

55.2004(1) SA 406(CC); also compare Islamic Unity Convention v IBA 2002 (4) SA 294 (CC) at [51].

56.Government of the Republic of South Africa v Sunday Times Newspaper 1995(2) SA $221(W)$ at 229 C-D.

57. Which, within this context, is not to be understood as that which is 'interesting to the public' - compare Financial Mail (Pty) Ltd and Others v Sage Holdings Ltd and Another 1993 (2) SA 451 (A) where Corbett CJ said in delivering the majority judgment (at 464C-D): '(1) There is a wide difference between what is interesting to judgment (at 464C-D): ' (1) There is a wide difference between what is interesting to
the public and what it is in the public interest to make known ... (2) The media have a private interest of their own in publishing what appeals to the public and may increase their circulation or the numbers of their viewers or listeners; and they are peculiarly vulnerable to the error of confusing the public interest with their own interest ...' Quoted with approval by Hoexter JA in Neethling v Du Preez; Neethling $v$ The Weekly Mail 1994 (1) SA 708 (A) at 779 and Hefer JA in National Media Ltd v Bogoshi \& Others 1998(4) SA 1196(SCA) at 1212 where reference is made to Asser Handleiding tot de Beoefening van het Nederlands Burgerlijk Recht (9th Ed vol III at 224 para 238: [translated]): 'In practice the public interest is especially employed in para 238: [translated]): 'In practice the public interest is especially employed in matters concerning views expressed via die printed media and television: public interest is, within this context, based on freedom of expression, as guaranteed by the Constitution and by treaties, to expose alleged abuse (and or evil in society). In deciding whether the defence of public interest was permissible the answer on the facts of each case' (emphasis in italics added to translation).

58.Section 39 of the Constitution. 
My personal view is that the presumption of innocence of the accused is more important than freedom of the press. Allow some speculation in publications, but do not pronounce on the verdict before the judge has done so. Weighing the evidence during the trial is also risqué. Fortunately judges, who are trained to decide a case on the facts before them, will not be influenced by speculation and views expressed in the media. In closing, I believe that it is appropriate to quote what Judge of Appeal Nugent $t^{59}$ said in a different context:

Opinions among reasonable men and women may differ. That is why we have politics. That is why, when it comes to political matters in a constitutional state such as ours, the courts will, as a general rule, hold their swords behind their backs. Ordinarily, moreover, the courts will, in such matters, hold the sword in their left hand and their shield in the right: the courts hold up the shield in preference to the sword when it comes to political matters of policy.

59. Minister of Home Affairs and Others v Scalabrini Centre and Others 2013 (6) SA 421 (SCA) at para [90].
The sub judice rule is, of course, not a political matter but it would seem sensible to seek alternative means and, if necessary, remedies outside the criminal law to protect the right of an accused to a fair trial. Only where the guidelines in Midi have been met clearly, intentionally and beyond a reasonable doubt, contempt of court will have been committed.

Ultimately jumping to conclusions in a publication or broadcast as to the outcome of a court case, whilst a matter is still being considered by a court, is at least morally unacceptable: to clearly contribute to such conclusions being made, is equally questionable.

\section{Acknowledgements Competing interests}

The author declares that he has no financial or personal relationship(s) that may have inappropriately influenced him in writing this article. 